\title{
NCI CTEP SDC Non-Rhabdomyosarcoma Soft Tissue Sarcoma Sub-Category Terminology
}

National Cancer Institute

\section{Source}

National Cancer Institute. NCI CTEP SDC Non-Rhabdomyosarcoma Soft Tissue Sarcoma

Sub-Category Terminology. NCI Thesaurus. Code C103117.

Non-Rhabdomyosarcoma Soft T issue Sarcoma is an NCl Cancer Therapeutic Evaluation Program (CTEP) Simplified Disease Classification (SDC) category used to organize cancer-related disease coding that harmonizes with and supports reporting based on the global standard Medical Dictionary for Drug Regulatory Reporting (MedDRA) terminology. 